\title{
On the Construction of Senior High School English Ecological Classroom from the perspective of Knowledge Management
}

\author{
Jia RUAN \\ School of Foreign Languages, Yibin University \\ Yibin, China \\ 535813128@qq.com
}

\begin{abstract}
As a new paradigm of educational research since last century, ecological classroom has thrown great light on the educational study. Under the background of the harmonious society, ecological classroom has already become the developmental trend of classroom construction, so that the research on measures of establishing senior high school English ecological classroom is a must. Inspired by the connotation of ecological classroom, I find that the popular concept of knowledge management which advocates people-oriented idea, knowledge sharing and innovation is a positive role to the construction of ecological classroom. Therefore, under the guidance of the approaches, principles and theories of ecological classroom and based on the theories, principles and approaches of knowledge management, the thesis applies both the literature research and experiential summary methods to research on measures of establishing senior high school English ecological classroom under the perspective of knowledge management in order to promote the ecological construction of English classroom in senior high school with two cents' worth.
\end{abstract}

Keywords-knowledge management; people oriented; knowledge innovation; senior high school English; ecological classroom; measures of construction

\section{INTRODUCTION}

With the development of the society, ecological classroom is gradually favored by many schools. Ecological classroom, which advocates returning to the nature, the overall harmony, the interaction, the open growth, sustainable development as well as people-oriented, is the ideal classroom and the new education pursuit. Ecological classroom is not only the place of students' learning, growing, and improving the quality of life, but also the mature stage of teachers' professional development. At the same time, it is not difficult to find that the popular concept of knowledge management which advocates people-oriented idea, knowledge sharing and innovation is a positive role to the construction of ecological classroom. Therefore, the thesis applies both the literature research and experiential summary methods to research on measures of establishing senior high school English ecological classroom under the perspective of knowledge management.

\section{KNOWLEDGE MANAGEMENT}

With the coming of knowledge age, knowledge has played decisive roles in all aspects of the society. There are all kinds of knowledge in the world; therefore, it is important to know some basic concepts and methods of knowledge management in order that individuals can be promoted to grasp, use and create knowledge.

knowledge is the understanding and experience obtained in practice based on the contacts among facts above information. According to OECD's report 'the knowledge- based economy' in 1996, knowledge is put into four categories: "Firstly, knowwhat is the knowledge concerned about facts. Secondly, know- why is the knowledge about the science theories of natural regularities. Thirdly, know-how is the knowledge concerned about the skills and abilities of completing something. Finally, know-who is about the knowledge of knowing others how to complete something.” (Du3-4)

The term 'Knowledge Management' was first put forward by the United Nations International Labor Organization. In the early time, knowledge management mainly depends on the development of information technology; therefore, the theory and practice concerned about knowledge management mainly revolve around information technology in the application of knowledge management. With the development of the society, studying knowledge management focuses on how to innovate knowledge. Up to now, knowledge management has not gotten a precise and clear definition; however, the researchers have their different understandings. For example, Bessie's opinion is that knowledge management is the process of knowledge creation, access and application for enhancing organizational performance. David J. Skyrme maintains that knowledge management is a series of scientific and systematic managements for knowledge creation, collection and organization. APQC holds the view that knowledge management is a meaningful strategy adopted, which guarantees to transmit the most needed information to the people who are in need and helps eople share the knowledge and information so that the information and knowledge can be put into action.” (Zeng 9)

Michael Polany, a physicist, chemist and philosopher divides knowledge into two categories of explicit knowledge 
and tacit knowledge according to different ways of knowledge acquisition and sharing. "Explicit knowledge which is easy to learn is the knowledge which can be described in written words, diagrams and mathematical formula. While tacit knowledge is the knowledge which presents high personality and the belief, world outlook, value system and insight based on personal experience.”(Du 14)

The following table demonstrates the differences between explicit knowledge and tacit knowledge.

Table I Comparison of explicit knowledge and tacit knowledge

\begin{tabular}{|l|l|l|}
\hline Characteristics & Explicit knowledge & Tacit knowledge \\
\hline Wepresentation & $\begin{array}{l}\text { Normative and } \\
\text { systematical } \\
\text { language }\end{array}$ & $\begin{array}{l}\text { Exist in human } \\
\text { being's brain and } \\
\text { difficult to use } \\
\text { formative language } \\
\text { and words to } \\
\text { present }\end{array}$ \\
\hline $\begin{array}{l}\text { Quantitative } \\
\text { characteristic }\end{array}$ & $\begin{array}{l}\text { Easy to quantify, } \\
\text { code and storage }\end{array}$ & $\begin{array}{l}\text { Difficult } \\
\text { quantify, code and } \\
\text { storage }\end{array}$ \\
\hline $\begin{array}{l}\text { Manifestation } \\
\text { Pattern }\end{array}$ & $\begin{array}{l}\text { Exist in teaching } \\
\text { materials, journals, } \\
\text { audio-visual media, } \\
\text { software and } \\
\text { database }\end{array}$ & $\begin{array}{l}\text { Exist in the forms of } \\
\text { experience, feelings } \\
\text { and habits }\end{array}$ \\
\hline $\begin{array}{l}\text { Acquisition } \\
\text { Way }\end{array}$ & $\begin{array}{l}\text { Learn by ways } \\
\text { and body }\end{array}$ & $\begin{array}{l}\text { Need experience } \\
\text { and practice to } \\
\text { acquire }\end{array}$ \\
\hline
\end{tabular}

It is necessary to exploit explicit knowledge. "One way to exploit explicit knowledge is to write information as personal notes: we are referring to the characteristic of some knowledge to be processed and then communicated using written and also verbal language. The accumulation of knowledge is not automatic, we need a 'prepared mind' when it comes to assimilating encoded knowledge." (Otilia-Maria BORDEIANU) Teaching strategies are chosen in traditional classroom based on the studying of the explicit knowledge. It is obvious that the traditional classroom has ignored the studying of tacit knowledge, leading to the lack of cultivating students' abilities of studying and exploring independently.

As a kind of management tool under the environment of information technology, knowledge management not only can be applied in the development of modern enterprise, also can play a significant role in classroom teaching. Therefore, according to the connotation of knowledge management and classroom tasks, it is reasonable to use knowledge management in the classroom teaching, which promotes teachers and students fully to obtain the explicit knowledge and tacit knowledge, so that the goal of knowledge creation can be fulfilled by the diffusion, using and sharing of knowledge.

\section{SENior High School English ECOlOGiCAl ClassRoOM}

As mentioned in the article Classroom of RESONANCE in March, 2015, “Classroom” is equally a forum for raising border issues and sharing personal experiences and viewpoints on matters related to teaching and learning science.

The classroom can be divided into broad sense and narrow sense classroom. Classroom in broad sense refers to the places with teaching activities' happening. The place can be called classroom as long as there are teaching activities. There is no time's limit and the places can be in the school, family or the society. However, the classroom in narrow sense only exists in the school education. The aim of narrow sense classroom is to pass and transform education knowledge to students, to develop students' intelligence and ability, and to cultivate students' moral character and thier personality.

The classroom is composed of many elements, such as the teacher, the student, the curriculum and the environment. Treating the curriculum as the carrier, the ecological subjects have contacts with each other in different environments. Teachers and students in ecological classroom have subjective initiative. It is unpredictable for each element to change in ecological classroom, such as the distribution of the class time, the relationship between teachers and students, and the process of the course. What's more, ecological classroom is a process in which teachers and students have common life experiences. In addition, it has the following characteristics:

"Firstly, it is natural and harmonious. That is to say, teachers should create a democratic, equal and harmonious atmosphere actively, guiding students to study in a relaxing environment. Secondly, it is animate. The life potential should be dug and the life value should be improved in ecological classroom. Thirdly, it is integral, open and developmental. Ecological classroom should promote the all-round, harmonious and sustainable development of the human being.”(Zhou 6)

In a word, ecological classroom is for the development of teachers and students, and it uses innovative way of teaching to promote students' sustainable development of life, studying and working habits, cultivate students' sustainable development of human responsibility, and create open mind and innovative quality.

As it mentioned, the teacher's role refers to the behavior model which is showed in the teaching system and it accords with the society's expectations to teachers by the determination of the teacher' special status. In the ecological classroom, teachers should make the classroom active and affirm students' progress. What's more, teachers use diversified teaching methods to stimulate students' interest in their learning. Besides, teachers choose the humorous contents to teach so that students feel comfortable and happy. Finally, it is indispensible for teachers to deal with students' materials use in ecological classroom. "Teachers are crucial participants who mediate the usage of materials and the ways in which resources and texts may or may not come to life for learners. The important ecological roles of teachers in materials use are self-evident, which connotes that teachers may skillfully select 
materials that best meet their pedagogical purposes.”(ANNE MARIE and BILL JOHNSTON)

"It is active students and dynamic classroom that make life be carnival.” This sentence can be a good description for the atmosphere of ecological classroom. "Education must follow the nature, or else it will inevitably produce the results of the injury of the nature." Rousseau said. Nature is harmonious, such as harmonious relationship between teachers and students, harmonious teaching and learning, the harmony among subjects, the harmony inside and outside of the class. Teachers and students will grow naturally in harmony.

Ecological classroom is the student-oriented classroom, which requires teachers to reflect the following four requirements in the classroom teaching. Firstly, it is to face all the students. Whether it is "top students" or "backward students" should be loved. Secondly, ecological classroom is for each student's all-round development. The attention is not only paid to students' understanding of the knowledge, but also students' emotion, attitude and value view. Thirdly, it is to develop students' personality. The multiple intelligence theory proposed by the American psychologist $\mathrm{H}$ Gardiner provides a theoretical basis on the development of the students with their own characteristics. Fourthly, the development of students should also be originally based on a sustainable development.

\section{USING THE TEMPLATE SENIOR High SCHOOL ENGLISH ECOLOGICAL Class BASEd ON KNOWLEDGE MANAGEMENT}

If we want to apply the idea of knowledge management to English ecological classroom, we must pay heed to the basic principles. The following principles of knowledge management applied in English classroom are put forward by $\mathrm{Li}$ chi, a teacher in school of foreign languages of Nanjing Aeronautics and Astronautics University. I found that those principles can also be applied in the senior high school English classroom.

1. The principle of strategy guiding. Due to the different teaching environment, organization structure, strategy target and characteristic of knowledge in different materials, teachers embrace different knowledge management strategies and directions in English classroom. Therefore, based on the teaching concept and organization structure of the course as well as the present situation of knowledge management, the strategies of knowledge management in classroom are supposed to be integrated into teachers' teaching strategies.

2. The principle of cultural priority. Knowledge management in English classroom has the purpose to cultivate the learning subject's cultural understandings or special interests of target language, which easily leads students actively to participate in the classroom.

3. The principle of management and fusion. Knowledge management in English classroom involves many facets, such as teachers, students, systems and behavior patterns. When applying knowledge management in English classroom, teachers should abandon the view of merely technical dependence, what should be done is that the methods, ideas and thoughts of knowledge management in English classroom is combined with the traditional teaching methods, systems and behavior patterns.

4. The principle of pragmatic emphasis. Knowledge management has the purpose of enhance learning effect. The important studying hot topics, themes and targets should be found to promote English classroom knowledge management in different period of time so that organization structure of English classroom and knowledge process of the text can be coherent.

5. The principle of technical support. It is hard to maintain the achievements of the promotion of knowledge management only from the perspective of language and culture, so appropriate technical tools should be used to protect the implementation of knowledge management in English classroom.

6. The principle of leadership. The key to the successful knowledge management is the training and education to teachers, and it is policy and financial support that are the secrets to successful knowledge management in English classroom.

7. The principle of continuous improvement. The methods and technical tools should be improved continuously.

As a means of management set up in the support of IT, knowledge management throws lights on English ecological classroom and plays a vital role in classroom teaching. From the perspective of ecological classroom teaching, the main task of knowledge management is to handle and integrate all kinds of information and related knowledge resources that the teachers and students face. At the same time, through the acquisition, transmission, sharing and sublimation, knowledge management is effectively used to promote the process of knowledge's spread and creation in classroom teaching. In addition, knowledge management refers to the management of both the explicit and the tacit knowledge. The assignments of knowledge management in English ecological classroom will be elaborated in details in the following. Firstly, the certain information technology should be used to deal with and integrate the information and knowledge of the school's, the teacher's and student's. In classroom teaching, knowledge management makes explicit knowledge appear in the form of standardization and manages tacit knowledge with appropriate methods, being aimed to stimulate the creativity of teachers and students. Secondly, when teachers pay attention to the learning of explicit knowledge, more attention should be paid to the studying of tacit knowledge. The teacher should try their best to make their tacit knowledge be accepted and innovated by students. Finally, carrying out knowledge management in the classroom teaching by means of understanding, acquisition, dissemination, utilization and sharing is beneficial to achieve the purposes of knowledge management creation on the basis of knowledge sharing. 
V. Designing Senior High SchoOl English EcOlOGiCAL

\section{ClASS FROM THE PERSPECTIVE OF KNOWLEDGE}

\section{MANAGEMENT}

Senior high school English ecological classroom is the classroom from the angle of ecology. Cultivating language ability is the essence of ecological classroom. In the teaching process, it is a must to embrace students' autonomy, group collaboration, interaction among students, interaction between teachers and students. At the same time, the knowledge sharing and knowledge construction is a must too. In addition, teachers participate in the classroom and dominate students who are the main body of the classroom. What's more, ecological classroom is the development of harmonious classroom. Now, the basic principles of ecological classroom construction from the angle of knowledge management will be firstly introduced.

1. The specific teaching goals. In senior high school, the student's English comprehensive ability should be effectively cultivated, teachers should firstly have basic theories of linguistics, figuring out the connotation of English comprehensive ability; Secondly, its connotation should be imparted to students subtly, making students understand the specific learning goals.

2. The scientific teaching content. Subject knowledge and pragmatic ability should be combined, which promotes language learning through discipline knowledge. Then it is advantageous for students to naturally combine listening, speaking, reading and writing the four language skills to complete the studying tasks.

3. The multimodal teaching method. In ecological classroom, transformation of the traditional teacher-centered and text-centered is a requirement. In addition, Internet and multimedia teaching technology should be used to meet the need of multimodal teaching method in order to let students participate in the activities of language. Such as role-playing, learning report, cooperative learning.

4. The independent studying process. Students should gain the initiative in learning and control their own learning behaviors, being active learners and explorers. Through effective knowledge management, students can embrace more interesting studying contents, so as to construct teachers' trust in students and students' initiative.

5. The harmonious relationship between teachers and students. The harmonious relationship between teachers and students is the embodiment of the ecological classroom, in which the teacher should help students discover, organize and manage knowledge. Teachers should show respect for the diversity of students because students have their own knowledge experiences, social backgrounds and emotional experiences.

6. The diversified evaluation model. Teachers should attach great importance to the process of classroom teaching and treat students' individual performance as the center, excavating the potential of students.
To some extent, senior high school English ecological classroom is to achieve positive interaction and dynamic balance among various kinds of factors in the teaching practice in the senior high school English classroom. Then I have some ideas about strategies of constructing English ecological classroom in senior high school from the perspective of knowledge management. Firstly, the relationship between teachers and students should be objectively recorded; therein to teachers and students can share their feelings. Secondly, the summary of the situation of the relationship between teachers and students should be done regularly, which leads both teachers and students to do introspection. In the next, by consulting relevant theories and resources, the rationality of the summary can be proved; and if there is something inappropriate with the summary, it can be continuously corrected in a long run. Finally, the summary will be shown in the class and be shared in the school, innovating in the process of sharing. So, a virtuous cycle can be built, which is not only beneficial to the construction of the class culture, but also conducive to the cultivation of the good relationship between teachers and students.

Cultivating the students' interest in learning English needs to create an active, humor, positive, equal atmosphere, letting students be not afraid of making mistakes and dare to speak English, so that the enthusiasm of students can be aroused in maximum by the diverse teaching methods, such as the means of the appreciation of English song and movie clips. In addition, auxiliary teaching, multimedia teaching can also be adopted. What's more, according to the teaching contents, teachers can design some related games and organize some competitions in order to stimulate students' interest in learning and excavate their potentials, which requires teachers to prepare a large number of resources before the class. In this moment, the knowledge management of teachers will play a great role in the class. With some software, teachers manage knowledge at ordinary time, collecting related knowledge and resources. At the same time, teachers can teach students what knowledge management is and how to manage knowledge, so that it develops students' good habits of knowledge management. By doing this, students will be more confident to play the main role in the class, which is conducive to the construction of a harmonious ecological classroom.

One of the factors of ecological classroom is the environment, which has an indispensable impact on classroom teaching. In order to make the classroom teaching go on wheels, the teacher, as a leading role, should spare no efforts to make the classroom atmosphere harmonious and vivid. To create a good classroom atmosphere, teachers should show respect for and forgive students, and they also should optimize the environment with organizing students. In addition, the teacher can also use the thought of knowledge management to build a harmonious classroom atmosphere. For example, after class activities, teachers can let students write feedback in order that the tacit knowledge can be transformed into the explicit knowledge. By this means, teachers can always keep communication with students, which is conducive to the classroom atmosphere constructing. At the same time, recording the feelings of activities can also add luster to the following activities. 
"There is no fixed method in teaching", which is the educator often mentioned, and it shows the dynamic classroom. In the process of teaching, teachers should adjust learning objectives and teaching contents in time according to the changes of students and related factors, maintaining the ecological balance of the classroom. At this moment, the teacher's knowledge management plays an indispensable role. That teachers form the good habit of knowledge management not only makes this classroom go on wheels effectively, but is advantageous to the unexpected situation in the classroom. And it is beneficial for teachers to extract the knowledge they need for the class.

\section{The Practice of Designing Senior High School}

\section{ENGLISH ECOLOGICAL CLASS FROM THE PERSPECTIVE OF}

\section{KNOWLEDGE MANAGEMENT}

With the development of science and technology, knowledge management is increasingly associated with the Internet. At the same time, the ecological classroom environment, which advocates the people-oriented concept, can also be done online. Therefore, with the support of the Moodle system, the platform, which includes the function of promoting senior high school English teachers' tacit knowledge and the function of senior high school English test, has been established by our paper team. In this platform, teachers and students can share the knowledge and experience of learning. At the same time, students can have a relatively real test environment, which helps their improvements of learning. In addition, compared with other systems, the Moodle system is more stable, teachers and students can continuously use this platform to obtain, innovate, and share their knowledge and experience. Finally, the students with poor achievements can learn the knowledge and experience of others on the basis of the tests according to their own needs, so that they can improve their interest in learning English, which is conducive to the sustainable development of the students as well as the construction of ecological classroom.

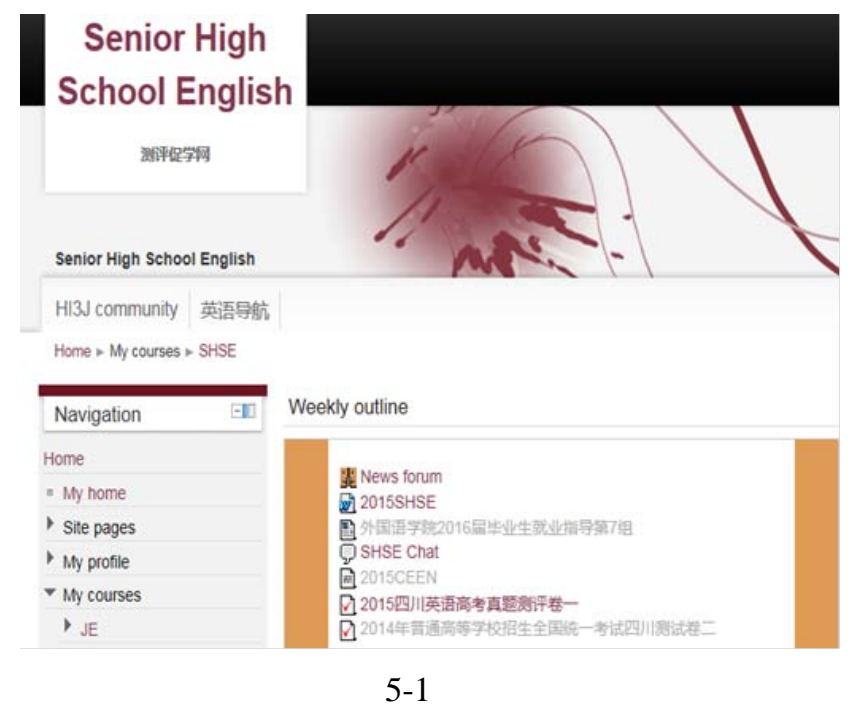

Picture5-1 is the home page of senior high school English promotion platform.

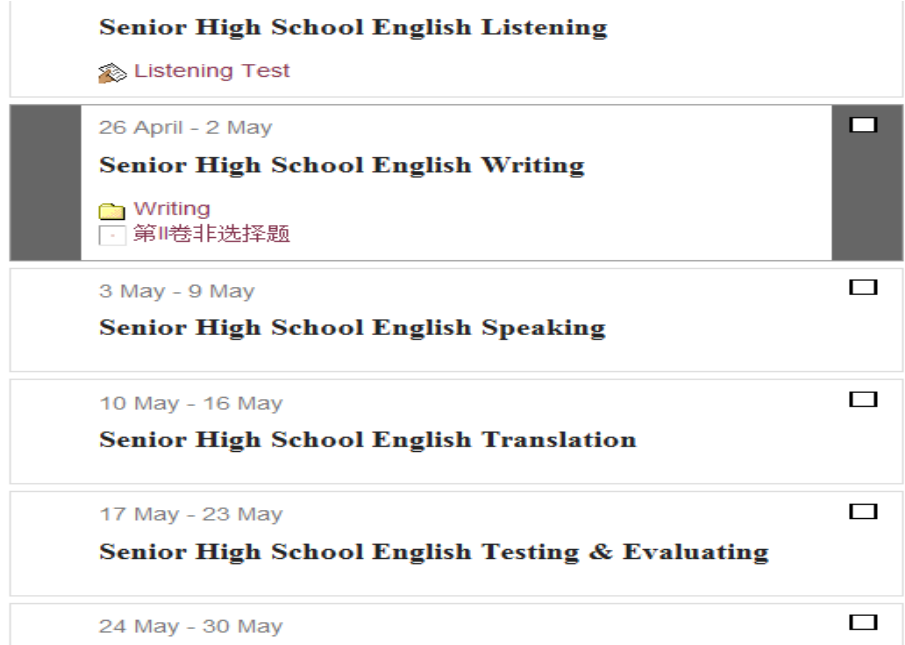

$5-2$

Picture5-2 shows the classifications of the test.

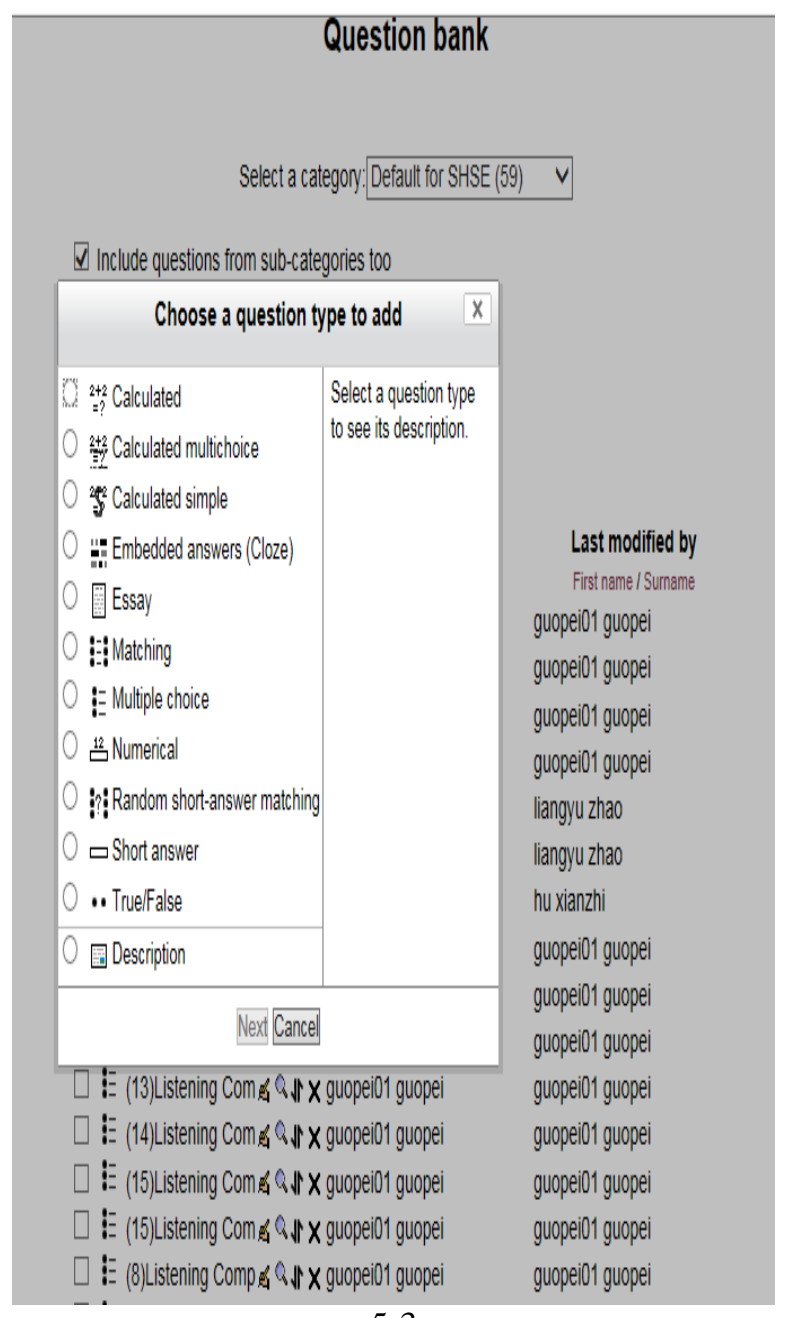
$5-3$

Picture5-3 demonstrates that teachers can construct different testing topics, including cloze, reading comprehension etc. 


\section{Preview 2015四川英语高考真题测评卷一}

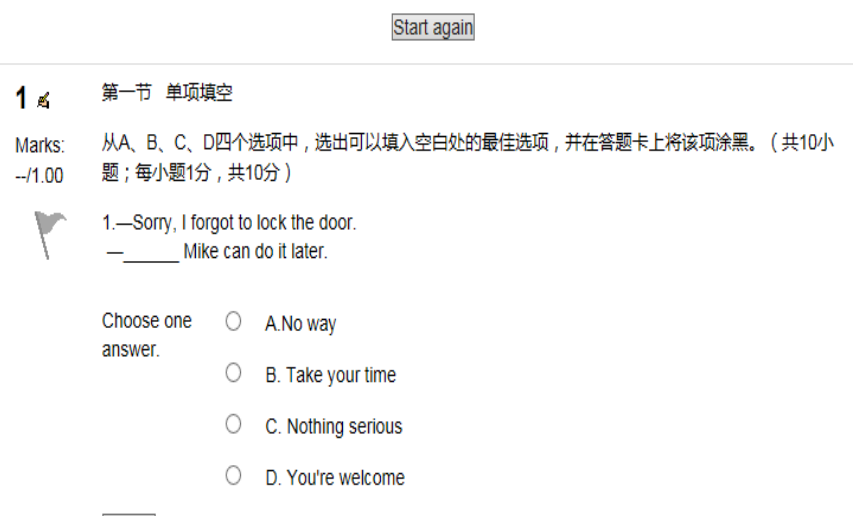

Submit

$5-4$

Picture5-4 is about the testing topic of the College Entrance Examination of English in 2015; and students can get feedback after doing test.

General > SHSE Chat

\section{SHSE Chat}

\section{Welcome!}

$$
\begin{aligned}
& \text { Click here to enter the chat now } \\
& \text { Use more accessible interface } \\
& \text { View past chat sessions }
\end{aligned}
$$

Picture5-5 shows that students and teachers can have a chat in this platform, in which they can share the experience of teaching and studying with others.

\section{CONCLUSION}

Ecological classroom is a kind of classroom in ecological condition. The construction of English ecological classroom in senior high school is to create the ecologically harmonious environment, to construct the ecological evaluation system with dynamic development, to establish democratic and equal ecological relationship between teachers and students, to build the interactive communication in ecological classroom. The characteristics of relation, openness, harmony and sharing are accordance with learning needs in the perspective of knowledge management. The ecological construction of senior high school English classroom is not only beneficial to students' all-round development, but is conductive to the creation of a new situation of the senior high school English classroom.

This paper has mentioned the related theories of knowledge management and the knowledge of senior high school English ecological classroom, together with the related views about the construction of senior high school English ecological classroom from the perspective of knowledge management. Meanwhile, the author had a deeper understanding of ecological classroom building in the process of writing the essay.

Objectively, the present research about the construction of English ecological classroom from the perspective of knowledge management is constrained by time, personal knowledge as well as personal energy. The width and depth of the research are far from satisfactory due to the fact that senior high school English ecological classroom involves complex and dynamic interaction between the ecological classroom subjects and objects. In the future study and work, I will pay more attention to the construction of English ecological classroom, striving for having deeper insights and more practice.

\section{Acknowledgment}

The author, Jia RUAN, would like to specify that this paper has been finished under my superviser's encouragement and assistance.

\section{References}

[1] ANNE MARIE and BILL JOHNSTON. "A Response: The Concept of the Classroom Ecology and the Roles of Teachers in Materials Use". The Modern Language Journal 98, 2014.

[2] “Classroom”, RESONANCE ,2015.

[3] Otilia-Maria BORDEIANU. “THE ROLE OF KNOWLEDGE MANAGEMENT AND KNOWLEDGE MANAGEMENT STRATEGIES WITHIN LEARNING ORGANIZATIONS”. ECOFORUM, 2015. in press.

[4] Zhou Hongli. "Study of Ecological High School English Classroom”. Central China Normal University, 2012.

[5] Du Mei[杜梅]. 知识管理在教学资源中的研究与应用 [D]. 北京: 北京 交通大学, 2010 .

[6] Li Chi[李迟]. 论英语教学中的课堂知识管理原则 [J]. 吉林省教育学 院学报, 2009. in press.

[7] Zeng Qiang[曾强]. 基于知识管理的高中英语网络学习平台的设计与 研究[D]. 上海: 华东师范大学, 2006. 